\title{
Second trimester abortion service at a provincial public hospital
}

\author{
Ram NareshPandit, Murari Thakur \\ Department of Obstetrics and Gynaecology, Provincial Hospital Janakpurdham, Nepal
}

Received: January 28, 2020

Accepted: May 5, 2020

\section{ABSTRACT}

Aims: To determine the demographic and clinical profile of clients receiving second trimester abortion service at a provincial hospital.

Methods: This is a retrospective study of second trimester abortion service provided at Provincial Public Hospital Janakpurdham at southern part of Nepal from 2014 to 2017. Data were collected from hospital record and analysis performed using MS Excel.

Result: There were 144 cases who received second trimester abortion service in four years. Annual clients' number linearly increased from 16 to 54 . Nearby people were the maximum clients. Majority (85\%) were multiparous and of early second trimester (12-15 weeks, $71 \%$ ). Common indication recorded was mental health (83\%) but lacks verification. Intervention method was combined (56\%) and contraception of choice was DMPA (44\%).

Conclusion: Demand of second trimester service is increasing every year. Indication of abortion needs to be scientifically verifiable. Injectable hormonal contraception is preferred by clients.

Keywords: abortion, client profile, second trimester

Citation : Pandit RN, Thakur M. Second trimester abortion service at a provincial public hospital. Nep J Obstet Gynecol. 2020;15(30):5557. DOI: 10.3126/njog.v15i1.29342

\section{INTRODUCTION}

Second trimester of pregnancy covers up to 28 weeks of pregnancy but the extrauterine viability fetus is considered from 20-22 weeks onwards only. ${ }^{1}$ Thus the second trimester abortion covers 12 to 22 weeks in this study. About $33 \%$ are unintended pregnancies and about $20 \%$ of them end in induced abortion. ${ }^{2}$ Globally, the incidence of second trimester termination of pregnancy is about $10 \%$ and they are the cause of a vast proportion of abortion related complications. ${ }^{3,4}$ Despite of high access to first-trimester services, the rate of second-trimester procedures remains relatively stable over time, indicating an ongoing need. ${ }^{5}$

The Government of Nepal initiated second-trimester abortion training in $2007 . .^{6}$ In spite of legalizing abortion and making safe abortion available at an affordable price at accessible distance to almost everyone the unsafe abortion, especially second trimester abortion is still a major health problem in Nepal. ${ }^{7,8}$

\section{CORRESPONDENCE}

Dr Murari Thakur

Provincial Hospital Janakpurdham, Province No 2, Nepal

Email: murarithakur45@gmail.com; Mobile: +977-9849042616
Provincial hospital Janakpurdham is the referral hospital in the Province-2. We have studied the demographic and obstetric profile of clients, indications, methods, complications and contraceptive method after second trimester abortion.

\section{METHODS}

This retrospective study was carried out at Provincial Hospital Janakpurdham. Medical records of all cases of second trimester abortions from 2014 to 2017 were included in the study. Record was kept on the register consisting of Client Personal Profile provided by Government of Nepal. ${ }^{9}$ Data were collected and descriptive analysis was done from MS Excel.

\section{RESULTS}

Number of clients per year was in increasing trend with highest being 54 in 2017 [Figure-1]. 


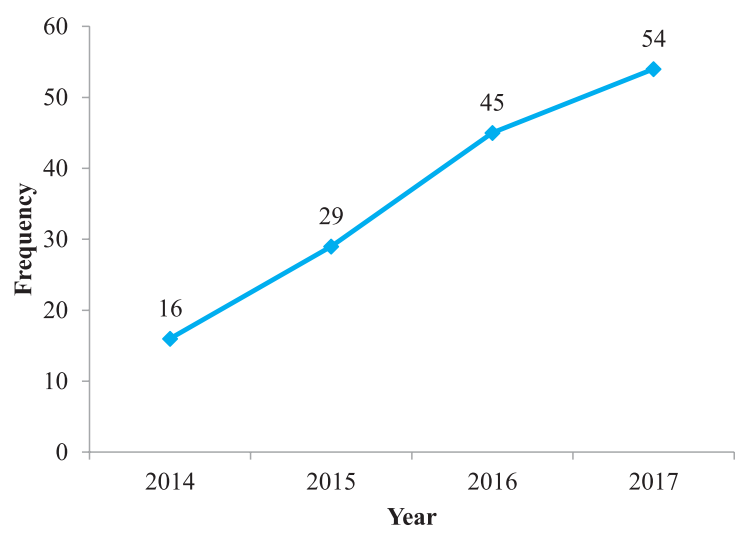

Figure-1: Annual distribution of second trimester abortions

Almost $90 \%$ of the clients were from 20-35 years age group with $2 / 3$ rd at 20-24 years; and $39 \%$ were illiterate clients [Table-1].

Table-1: Demographic profile of clients receiving second trimester abortion service $(n=144)$

\begin{tabular}{|c|c|c|c|}
\hline \multicolumn{2}{|c|}{ Parameters } & $\mathbf{N}$ & Percentage \\
\hline \multirow[t]{7}{*}{ District } & Dhanusa & 107 & 74.3 \\
\hline & Mahottari & 23 & 16.0 \\
\hline & Sirha & 5 & 3.5 \\
\hline & Sarlahi & 4 & 2.8 \\
\hline & Sindhuli & 3 & 2.1 \\
\hline & Saptari & 1 & 0.7 \\
\hline & Rautahat & 1 & 0.7 \\
\hline \multirow[t]{5}{*}{ Caste } & Dalit & 6 & 4.2 \\
\hline & Janjati & 5 & 3.5 \\
\hline & Madhesi & 122 & 84.7 \\
\hline & Muslim & 4 & 2.8 \\
\hline & Others & 7 & 4.9 \\
\hline \multirow{6}{*}{$\begin{array}{l}\text { Age group } \\
\text { in years }\end{array}$} & $15-19$ & 10 & 6.9 \\
\hline & $20-24$ & 46 & 31.9 \\
\hline & $25-29$ & 48 & 33.3 \\
\hline & $30-34$ & 35 & 24.3 \\
\hline & $35-39$ & 4 & 2.8 \\
\hline & $40+$ & 1 & 0.7 \\
\hline \multirow[t]{4}{*}{ Education } & Illiterate & 57 & 39.6 \\
\hline & Primary level & 22 & 15.3 \\
\hline & Secondary level & 61 & 42.4 \\
\hline & Higher secondary + & 4 & 2.8 \\
\hline
\end{tabular}

Most of the clients were multiparous (78.5\%) at early second trimester (71\%) [Table-2].

Table-2: Obstetric profile of clients $(n=144)$

\begin{tabular}{|l|l|c|c|}
\hline \multicolumn{2}{|c|}{ Parameters } & N & Percentage \\
\hline \multirow{3}{*}{$\begin{array}{l}\text { Weeks of } \\
\text { gestation }\end{array}$} & $12-15^{+6}$ & 102 & 70.8 \\
\cline { 2 - 4 } & $16-19^{+6}$ & 36 & 25.0 \\
\cline { 2 - 4 } & $20-22$ & 6 & 4.2 \\
\hline \multirow{3}{*}{ Parity } & Nulliparous & 12 & 8.3 \\
\cline { 2 - 4 } & Multiparous & 113 & 78.5 \\
\cline { 2 - 4 } & Grandmultiparous & 19 & 13.2 \\
\hline
\end{tabular}

Indications for abortions were mental health condition in $83.3 \%$ and fetal anomaly in $16.7 \%$ but their details were not available. Medical method of intervention was in $43.7 \%$ and combined (medical + surgical) method was used in $56.3 \%$. In complication part, incomplete abortion was in $7(4.9 \%)$ and excessive bleeding in $3(2 \%)$ of cases.

Only $13 \%$ deferred to use post-abortion contraception and maximum clients chose injectable hormonal contraception (DMPA) followed by Condom and oral combined pills (COC) [Table-3].

Table-3: Choice of post-abortion contraceptive method $(n=144)$

\begin{tabular}{|l|c|c|}
\hline \multicolumn{1}{|c|}{ Contraceptive methods } & N & Percentage \\
\hline DMPA & 63 & 43.8 \\
\hline Condom & 26 & 18.1 \\
\hline COC & 24 & 16.7 \\
\hline IUCD & 6 & 4.2 \\
\hline Implant & 4 & 2.8 \\
\hline Minilap & 2 & 1.4 \\
\hline (None) & 19 & 13.2 \\
\hline
\end{tabular}

\section{DISCUSSION}

In this study the annual incidence of second trimester abortion seemed to be in increasing trend. This could be the result of safe abortion awareness programs of Ministry of Health. This also indicates the belief and attraction of clients toward abortion care service of government hospital. However, it is difficult to generalize the result as this study includes the data from single hospital.

Provincial hospital Jananakpurdham is situated in Dhanusa district so most patient belonged to this 
district. Most of the clients were under 30 years of age, poor literacy rate and multiparous which are similar to the findings of Karkiet $\mathrm{al}^{10}$ and Shrivastva et al. ${ }^{11}$

In this study maternal mental health was major indication for second trimester abortion which was similar to that of Karkiet al ${ }^{10}$ but contrary to that of Anderson $\mathrm{N}$ et $\mathrm{al}^{12}$, Boyd PA et $\mathrm{al}^{13}$ and Shaffer BL et $\mathrm{al}^{14}$ where majority had some anatomic or genetic anomalies of fetus. Similarly Shrivastvaet $\mathrm{al}^{11}$ also had different result where unwanted pregnancy due to various reasons was major indication. Verifiable data were not available for the recorded indications such as diagnosis of mental health and fetal anomaly. Thus the verification of these indications is required to have the valid data.

In this study most of the clients underwent medical induction followed by dilatation and evacuation $(56.25 \%)$ that is similar to the reports of Karki et $\mathrm{al}^{10}$ and Chhetri et al. ${ }^{15}$ However these studies have not mentioned about the complications occurred during the procedure but we observed that few cases had retained POC and excessive bleeding leading to blood transfusion.

Most client in this study opted for Inj DMPA as post abortion family planning method followed by condoms and oral pills. However permanent methods were not much preferred. This was different from that observed by Karkiet $\mathrm{al}^{10}$ and Chhetri et al. ${ }^{15}$

\section{CONCLUSIONS}

There is increasing demand of second trimester abortion service every other year. Majority of clients were in between 20 and 30 years and multipara. DMPA followed by condom and oral pills were the preferred methods of post-abortion contraceptives. There is lack of verifiable indications like mental health and fetal anomaly.

\section{REFRENCES}

1. Cunningham FG, Leveno KJ, Bloom SL, Spong CY, Dashe JS, Hoffman BL et al, editors. Williams Obstertics. 24th ed New York: McGraw Hill Education; 2014.

2. Shah I, Ahman E. Unsafe abortion in 2008: global and regional levels and trends. Reproductive health matters. 2010;18(36):90-101. URL: https:/www.ncbi.nlm.nih.gov/ pubmed/21111353.

3. Gemzell-Danielsson K, Lalitkumar S. Second trimester medical abortion with mifepristone-misoprostol and misoprostol alone: a review of methods and management. Reproductive Health Matters. 2008;16(sup31):162-72. URL: https:/www. ncbi.nlm.nih.gov/pubmed/18772097.

4. Jones RK, Finer LB. Who has second-trimester abortions in the United States?. Contraception. 2012;85(6):544-51. URL: https://www.ncbi.nlm.nih.gov/pubmed/22176796.

5. Harries J, Orner P, Gabriel M, Mitchell E. Delays in seek ing an abortion until the second trimester: a qualitative study in South Africa. Reproduct Health. 2007;4(1):7. URL: https://reproductive-health-journal.biomedcentral.com/articles/10.1186/1742-4755-4-7.

6. Baldwin M, Basnett I, Dangol D, Karki C, Castleman L, Edelman A. Notes from the field: expanding abortion services into the second trimester of pregnancy in Nepal (2007-2012). Contraception. 2014;90(6):562-4. URL: https://www.ncbi. nlm.nih.gov/pubmed/25266926.

7. Aniteye P, Mayhew S. Attitudes and experiences of women admitted to hospital with abortion complications in Ghana. African J Reproduct Health. 2011;15(1). URL: https://www ajol.info/index.php/ajrh/article/view/67856.

8. Mentula MJ, Niinimäki M, Suhonen S, Hemminki E, Gissler $\mathrm{M}$, Heikinheimo O. Immediate adverse events after second trimester medical termination of pregnancy: results of a nationwide registry study. Human reproduction. 2011;26(4):927-32. URL: https:// www.ncbi.nlm.nih.gov/pubmed/21317416
9. K.C N, Paudel P, Kafle K, Basnet D. Revised SAS Guidelines 2074. Kathmandu: Government of Nepal, MoH, DoHS, Family Health Division, 2017. 68p (Nepali language). URL:http:// www.fhd.gov.np/index.php/nep/publications/171-revisedsas-guideline-2074-final

10. Karki A, Dangal G, Pradhan HK, Shrestha R, Bhattachan $\mathrm{K}$. Medical and Surgical Abortion in the Second Trimester of Pregnancy. Nep J Obstet Gynaecol. 2015;10(1):25. URL: https://www.nepjol.info/index.php/NJOG/article/view/13189

11. Shrivastava V, Bajracharya L, Thapa S. Surgical abortion in second trimester: initial experiences in Nepal. Kathmandu Univ Med J. 2010;8(2):169-72. URL: https://www.nepjol. info/index.php/KUMJ/article/view/3552

12. Anderson N, Boswell O, Duff G. Prenatal sonography for the detection of fetal anomalies: results of a prospective study and comparison with prior series.Amer $\mathrm{J}$ Roentgenolog. 1995;165(4):943-50. URL: https://www.ncbi.nlm.nih.gov/ pubmed/7676997.

13. Boyd PA, DeVigan C, Khoshnood B, Loane M, Garne E, Dolk H, EUROCAT Working Group. Survey of prenatal screening policies in Europe for structural malformations and chromosome anomalies, and their impact on detection and termination rates for neural tube defects and Down's syndrome. BJOG. 2008;115(6):689-96. URL: https://www.ncbi.nlm.nih. gov/pubmed/18410651.

14. Shaffer BL, Caughey AB, Norton ME. Variation in the decision to terminate pregnancy in the setting of fetal aneuploidy. IntSocPrenat Diagnosis. 2006;26(8):667-71. URL: https:// www.ncbi.nlm.nih.gov/pubmed/16724363.

15. Chhetri S. Assessment of the Efficacy of Different Methods of Second Trimester Abortion: An Initial Experience in Eastern Nepal. JSAFOG. 2015;7(3):182-4. URL: https://pdfs.semanticscholar.org/c995/9f557a4dafa9c290ee1269cac4a38b29c7 9b.pdf. 